\title{
Eradication of Plant Pathogens in Forest Nursery Irrigation Water
}

\author{
Patrícia da S. Machado, Acelino C. Alfenas, and Marcelo M. Coutinho, Plant Pathology Department; Cláudio M. Silva, Forest \\ Engineering Department; Ann H. Mounteer, Civil Engineering Department; and Luiz A. Maffia, Rodrigo G. de Freitas, and Camila \\ da S. Freitas, Plant Pathology Department, Federal University of Viçosa, Viçosa, MG, 36570-000, Brazil
}

\begin{abstract}
Machado, P. da S., Alfenas, A. C., Coutinho, M. M., Silva, C. M., Mounteer, A. H., Maffia, L. A., Freitas, R. G. de, and Freitas, C. da S. 2013. Eradication of plant pathogens in forest nursery irrigation water. Plant Dis. 97:780-788.

Interest in rational use and reuse of water has increased in recent years, especially in forest nurseries. However, before water can be reused in nurseries, it must be properly treated to eradicate plant pathogens to reduce risks of pathogen dispersal and losses to disease. In the present study, the efficacy of irrigation water treatment by ultrafiltration and conventional physical-chemical treatment was studied to eliminate Botrytis cinerea, Cylindrocladium candelabrum, Ralstonia solanacearum, and Xanthomonas axonopodis, the pathogens most commonly found in Brazilian forest nurseries. Ultrafiltration eradicated over $99 \%$

of $R$. solanacearum, X. axonopodis, and B. cinerea and $100 \%$ of $C$. candelabrum. The few remaining cells or conidia of $R$. solanacearum and $B$. cinerea did not induce disease in irrigated rooted cuttings. Flocculation and fast sand filtration used in physical-chemical treatment completely eliminated $C$. candelabrum but the other pathogens were only removed after chlorination of the filtered water. Both forms of treatment are viable, practical, and safe methods for plant pathogen removal from irrigation water.
\end{abstract}

Water is an increasingly limited natural resource which is in high demand for agricultural production. Worldwide, 60 to $90 \%$ of available water is used for agricultural purposes (36). In Brazil, it is estimated that $70 \%$ of water is consumed in agriculturally related activities (29). One such economically important activity in Brazil is production of Eucalyptus spp. by rooted cuttings or seedlings in forest nurseries, which may utilize surface waters (rivers, streams, lakes, and reservoirs), well water, and precipitation to meet their demands. Water consumption in forest nurseries was reported to vary from 35 to 49 liters/day per thousand cuttings, with $70 \%$ of the total consumption destined for the growth and hardening phases of plant production (40). In a preliminary survey, water consumption in eight clonal eucalypt nurseries was found to vary from 9 to 38 liters/day per thousand cuttings (unpublished data). Only two of the nurseries relied solely upon well water, while the rest depended on two or more surface water sources. Furthermore, most nurseries had rainwater collection or drainage systems and discharged the rainwater along with nursery wastewater.

With the recent increases in nursery production and public pressure to preserve natural resources, coupled with the increasing scarcity of adequate water supplies, interest in rational use and reuse of nursery irrigation water is on the rise. The practice of recycling irrigation water increases the amounts of nutrients in the water (50) and can result in savings of 50\% of fertilizer and $30 \%$ of fresh water consumed (52). However, recycled water may be contaminated with plant pathogens, such as propagules of fungi (44) and Oomycota $(27,53)$, bacterial cells or spores $(13,34)$, and nematodes (11). Therefore, recycled water may be an important source of pathogen dispersal leading to significant losses in nursery production $(32,41)$. Analyses of untreated irrigation water from different phases of eucalypt clonal propagation showed that spores of Botrytis cinerea Pers. and Cylindrocladium candelabrum Viégas are often found (28). Other organisms commonly associated with eucalypt cutting infections and that are dispersed rapidly in nurseries in warm, nutrient-rich irrigation water

Corresponding author: A. C. Alfenas, E-mail: aalfenas@ufv.br

Accepted for publication 5 January 2013.

http://dx.doi.org/10.1094/PDIS-08-12-0721-RE

(C) 2013 The American Phytopathological Society include Xanthomonas spp. and Ralstonia solanacearum (Smith) Yabuuchi et al. (55).

Treatment of irrigation water before reuse is a viable alternative for reducing fresh water consumption and the risk of disease in plant nurseries. Various water treatment methods are available, including conventional physical-chemical treatment (coagulation, flocculation, sedimentation, filtration, and chlorination), membrane filtration, ozonation, pasteurization, slow sand filtration, and ultraviolet radiation. The treatment method chosen by end users depends on raw or recycled water quality, volume of water usage, and cost.

Conventional physical-chemical treatment is the most widely used process in public water treatment plants (PWTP) (26). The treatment process includes rapid mixing, flocculation, sedimentation, fast sand filtration, and disinfection. Aluminum or iron salts are typically used as coagulants in the rapid mixing step. These coagulants hydrolyze and form gelatinous precipitates that interact with suspended solids (e.g., fungal and bacterial propagules) to form flocs. During flocculation, the water is slowly agitated to increase the flocs to a size at which they decant during sedimentation (9). Clarified water from the sedimentation tank is then filtered in a sand bed to remove remaining flocs and, finally, chlorinated to eradicate pathogenic microorganisms (31). The most commonly used disinfectant (chlorine) can be added in the form of gas $\left(\mathrm{Cl}_{2}\right)$ or as sodium hypochlorite $(\mathrm{NaOCl})$ or calcium hypochlorite $\left(\mathrm{Ca}(\mathrm{OCl})_{2}\right)$. Chlorine hydrolyzes in water to form hypochlorous acid + hypochlorite ion $\left(\mathrm{HOCl} \rightarrow \mathrm{OCl}^{-}+\mathrm{H}^{+}\right)$. The sum of hypochlorous acid and hypochlorite ion present is termed free residual chlorine. The proportion of the nonionized and ionized forms is $\mathrm{pH}$ dependent and, because the nonionized form is a more efficient oxidant, the chlorine contact time should be run at $\mathrm{pH} \leq 8$. Disinfection with chlorine is due to oxidative damage of the microbial cell wall and membrane, followed by chlorine diffusion into the cell and alteration of vital cell functions (26). High free residual chlorine concentrations in irrigation water may induce plant toxicity and reduce seedling growth and development.

Membrane filtration is classified according to membrane pore size: microfiltration $(0.1$ to $10 \mu \mathrm{m})$, ultrafiltration $(0.02$ to $0.1 \mu \mathrm{m})$, and nanofiltration (500 to $20,000 \mathrm{Da}$ ) (10). Membrane filtration has been successfully used to remove plant pathogens in irrigation water and hydroponic solutions $(15,22,36,42,47)$. This treatment process is highly efficient and, because it does not require addition of any chemical products, membrane filtration does not chemically alter the nutrient content of the water supply $(36,42)$. 
Slow sand filtration is one of the oldest methods known for treating water. The method is simple and involves two processes, the physical process in which water slowly percolates (100 to 300 liter $/ \mathrm{m}^{2} / \mathrm{h}$ ) through the sand bed forming a physical barrier and the biological process due to microbial antagonists (biofilm) on the surface of the sand bed (10). There is no need to employ chemicals or sophisticated equipment for process control. This method was able to completely eliminate $B$. cinerea and $C$. candelabrum inocula and remove up to $99.6 \%$ of $R$. solanacearum colonies from forest nursery recycled water (12) and achieved $98.8 \%$ removal efficiency of Xanthomonas campestris pv. perlargonii from a geranium closed-cropping system (54).

Given the wide variety of waterborne diseases that may afflict eucalypt cutting production and the interest in finding ways to safely reuse irrigation water, the present study was undertaken to evaluate the efficacy of conventional physical-chemical treatment and ultrafiltration of irrigation water in eliminating common fungal and bacterial plant pathogens and determine the residual free chlorine concentration needed to eradicate these pathogens.

\section{Materials and Methods}

Plant pathogens tested. The plant pathogens $B$. cinerea $(\mathrm{BC}$ 01), C. candelabrum (CyC 01), R. solanacearum (UFV 34), and X. axonopodis (BSC 475) were used to experimentally contaminate irrigation water. These pathogens were chosen because they commonly cause disease of cuttings in Brazilian eucalypt clonal nurseries (2). All isolates were obtained from the Forest Pathology Laboratory, Plant Pathology Department, Federal University of Viçosa (UFV).

Rifamycin SV-resistant $R$. solanacearum (UFV 34) and $X$. axonopodis (BSC 475) isolates were used to facilitate their detection after water contamination. These isolates were grown for $48 \mathrm{~h}$ at $28^{\circ} \mathrm{C}$ on solid 523 medium (24), supplemented with rifamycin SV at $0.2 \mathrm{mg} / \mathrm{ml}$ for $R$. solanacearum or $0.1 \mathrm{mg} / \mathrm{ml}$ for $X$. axonopodis.

Rifamycin SV-resistant pathogenic isolates were detected using hypersensitivity tests in tobacco (Nicotiana tabacum 'Havana 425') for $R$. solanacearum and in tomato (Solanum lycopersicum 'Santa Clara') for X. axonopodis (25). Afterward, the isolates were inoculated in the original host to confirm the pathogenicity. The identity of $R$. solanacearum isolates was also confirmed by polymerase chain reaction (PCR). Genomic DNA was extracted (18) and amplified by PCR using primers PS1 (5'-agtcgaacggca gcggggg- $\left.3^{\prime}\right)$ and PS2 (5'-ggggatttcacatcggtcttgca- $\left.3^{\prime}\right)$ that amplified a 553-bp region of the $16 \mathrm{~S}$ RNA gene (37). The reaction was carried out in solution containing $10 \mathrm{mM}$ Tris- $\mathrm{HCl}(\mathrm{pH} 8.3), 50 \mathrm{mM}$ $\mathrm{KCl}, 2.5 \mathrm{mM} \mathrm{MgCl}{ }_{2}, 0.2 \mathrm{mM}$ each deoxynucleotide (dATP, dTTP, $\mathrm{dCTP}$, and dGTP), $0.4 \mu \mathrm{M}$ each primer, 1 unit of Taq DNA polymerase, and sterile deionized water in a final volume of $15 \mu \mathrm{l}$. Reactions were carried out in a PTC-100 thermocycler (MJ Research, Inc.), following previously described conditions (37). The PCR product was analyzed in a $1.6 \%$ agarose gel in Tris-acetate EDTA stained with ethidium bromide $(0,5 \mu \mathrm{g} / \mathrm{ml})$. Deionized water was used as negative control and $R$. solanacearum (UFV 34) from the Forest Pathology Laboratory collection (UFV) was used as positive control to evaluate reaction specificity.

To produce bacterial suspensions for contamination of irrigation water, bacterial isolates were grown on solid 523 medium (24) supplemented with rifamycin SV at $0.2 \mathrm{mg} / \mathrm{ml}$ ( $R$. solanacearum) or $0.1 \mathrm{mg} / \mathrm{ml}$ (X. axonopodis) and incubated at $28^{\circ} \mathrm{C}$ in the dark. After $48 \mathrm{~h}$, bacterial growth was harvested in sterile saline solution $(0.85 \% \mathrm{NaCl})$ and the suspensions were adjusted to an optical density at $540 \mathrm{~nm}\left(\mathrm{OD}_{540}\right)$ of 0.2 for $R$. solanacearum and 0.1 for $X$. axonopodis. These $\mathrm{OD}_{540}$ values corresponded to approximately $1 \times 10^{8} \mathrm{CFU} / \mathrm{ml}$. All inoculum suspensions for the infestation in both water treatment methods were prepared with a saline solution $(0.85 \% \mathrm{NaCl}$ in distilled water).

The fungal isolates $B$. cinerea and $C$. candelabrum were transferred to potato dextrose agar (PDA) and incubated for about 20 days at $20^{\circ} \mathrm{C}$ (B. cinerea) or $26^{\circ} \mathrm{C}($ C . candelabrum $)$ in the dark. Conidia of $B$. cinerea were harvested in sterile distilled water con- taining $0.05 \%$ Tween 20 . The suspension was filtered in cheesecloth and adjusted to $1 \times 10^{5}$ conidia/ml (33). Sporulation of $C$. candelabrum was induced by physical stress. For this, all aerial mycelia were removed from culture surface with a sterilized paint brush and the culture was subsequently kept submerged for 2 days in sterile distilled water. After this period, the water was discarded and the culture was blotted dry using sterile gauze. The culture was maintained under laboratory conditions $\left(26 \pm 5^{\circ} \mathrm{C}\right)$ for 2 days (17). A suspension of $1 \times 10^{4}$ conidia $/ \mathrm{ml}$ was prepared as described for $B$. cinerea. All inoculum suspensions used for infestation in both water treatment methods were prepared with distilled water.

Efficacy of ultrafiltration of contaminated irrigation water. The ultrafiltration unit consisted of a synthetic, hollow fiber polymeric ultrafiltration membrane module submerged in a feed tank (24 liters in capacity), to which the pathogens were added (Fig. 1). Membranes ( $3 \mathrm{~mm}$ in diameter by $25 \mathrm{~cm}$ long) with $0.05-\mu \mathrm{m}$ diameter pore size and total surface area of $0.5 \mathrm{~m}^{2}$ were used. The system was operated at a continuous flow of $40 \mathrm{ml} / \mathrm{min}$ in a closed cycle. The filtered water entered a secondary reservoir from which it returned to the feed tank containing untreated water. In this way, the contaminating suspension volume was held constant. Flow across the membranes was achieved using a peristaltic pump that produced a vacuum and caused water to enter into the hollow membranes. Compressed air was injected into the feed tank to reduce formation of deposits and membrane blockage.

Membranes were washed with distilled water and examined for leaks after each test. For each pathogen, the ultrafiltration unit was operated for 7 days, with each 1-day period being considered a repetition of the experiment. In order to assure sufficiently high pathogen suspensions in the feed tank over the 7-day period, fresh bacterial suspensions were added to the feed tank on days 1 and 4, and fungal suspensions were added on days 1, 3, and 5. For each infestation, the inoculum volumes added to the 24-liter feed tank were adjusted to obtain the final concentrations previously described. Samples of contaminated raw and ultrafiltered water (50 $\mathrm{ml}$ each) were collected separately in sterile Falcon tubes (TPP, model 901050). Three 50-ml samples of contaminated raw and ultrafiltered water were collected at 8:00 a.m., three at 12:00 p.m.,

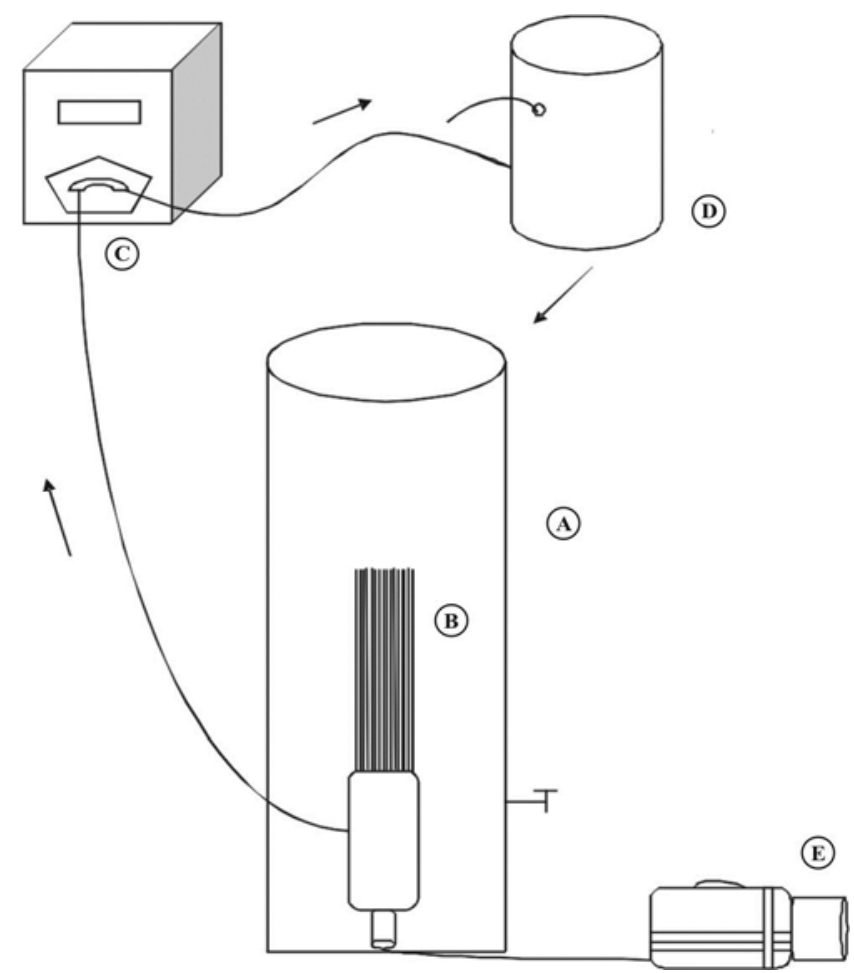

Fig. 1. Ultrafiltration system: A, feed tank containing contaminated raw water; B, membrane cartridge; C, peristaltic pump; D, second tank containing treated water; and $\mathbf{E}$, compressed air pump. Arrows indicate water flow. 
and three at 6:00 p.m. Therefore, the experiment included two treatments (contaminated raw water and ultrafiltered water) with seven repetitions (days), each day with three replications (times in a day). In each replication, three samples were taken, the counts were pooled, and each day ended with nine observations.

Physical-chemical treatment of contaminated water. Before initiating the experiment, the residual chlorine dose needed for pathogen inactivation and the phytotoxicity of residual chlorine in irrigation water were determined. Pathogen suspensions were prepared and final concentrations were adjusted as previously described. The chlorine dose used in the conventional treatment was chosen based on the lowest residual chlorine able to eradicate all four pathogens tested. Sodium hypochlorite solution $(20 \mathrm{mg} / \mathrm{liter}$, $\mathrm{pH}$ 6.5) was added to the pathogen suspensions in a final volume of $30 \mathrm{ml}$. Sodium hypochlorite was adjusted to reach final concentrations of $0,1,2,4,6$, and $8 \mathrm{mg} / \mathrm{liter}$. The suspensions were mixed for $30 \mathrm{~min}$; then, 1-ml aliquots were transferred to Eppendorf tubes containing $1 \mu \mathrm{l}$ of $3 \%$ sodium thiosulfate $\left(\mathrm{Na}_{2} \mathrm{~S}_{2} \mathrm{O}_{3}\right)$ to destroy the residual chlorine. The remaining $29 \mathrm{ml}$ of the samples was used to measure free residual chlorine using the $N, N$-diethyl- $p$-phenylenediamine colorimetric method (Hach Pocket Colorimeter II). Eppendorf tubes containing bacterial pathogens and sodium hypochlorite + sodium thiosulfate were centrifuged at $10,000 \times g$ for $10 \mathrm{~min}$ and the resulting pellets were resuspended in $1 \mathrm{ml}$ of saline solution, then subjected to 10 -fold serial dilutions $\left(10^{-1}\right.$ to $\left.10^{-8}\right)$. Each dilution was transferred using the microdrop technique (10 $\mu 1)(25)$, without spreading, to petri plates containing solid 523 medium (24) supplemented with 0.2 rifamycin at $\mathrm{mg} / \mathrm{ml}$ ( $R$. solanacearum) or $0.1 \mathrm{mg} / \mathrm{ml}$ (X. axonopodis). Plates were then maintained at $28^{\circ} \mathrm{C}$ for $48 \mathrm{~h}$ in the dark. Aliquots of $100 \mu \mathrm{l}$ from each Eppendorf tube containing fungal pathogens and sodium hypochlorite + sodium thiosulfate were spread on PDA in petri plates that were maintained at $20^{\circ} \mathrm{C}$ (B. cinerea) or $26^{\circ} \mathrm{C}($ C. candelabrum $)$ for $48 \mathrm{~h}$ in the dark. Each colony formed from one germinated conidia was considered $1 \mathrm{CFU}$.

After incubation, CFU were counted and treatment efficiency was evaluated. Controls were prepared from pathogen suspensions in sterile saline solution with and without added sodium thiosulfate. Five replications were used per treatment.

For each pathogen, the experiment was carried out twice, each in a completely randomized design with six treatments (sodium hypo-

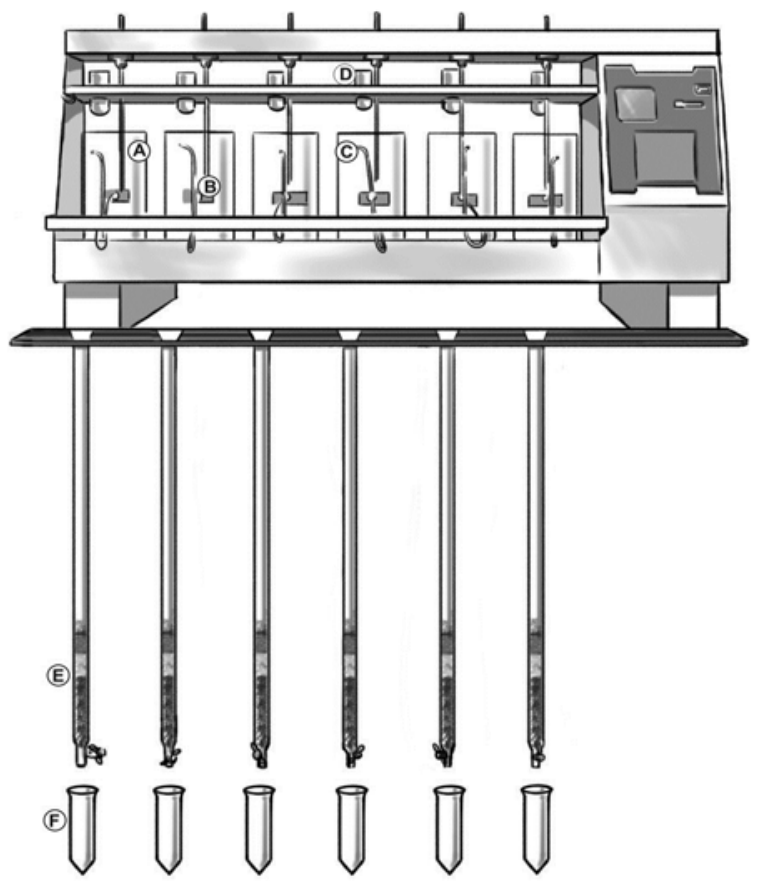

Fig. 2. Jar test: A, jar; B, mixer; C, spigot for sample collection; D, aluminum sulfate $\left(\mathrm{Al}_{2}\left(\mathrm{SO}_{4}\right)_{3}\right)$ dosing cup; $\mathrm{E}$, sand filter; and $\mathbf{F}$, falcon tubes for collecting filtered water. chlorite concentrations) and five replications, one tube being considered one experimental unit.

Efficacy of physical-chemical treatment of contaminated water. Conventional water treatment was simulated in a jar test apparatus (Fig. 2). Aluminum sulfate $\left(\mathrm{Al}_{2}\left(\mathrm{SO}_{4}\right)_{3}\right)$ was added to each 2liter capacity jar under rapid mixing for $10 \mathrm{~s}$ at a velocity gradient (G) of $\mathrm{G}=1,000 / \mathrm{s}( \pm 300 \mathrm{rpm})$. The mixing intensity was reduced to initiate flocculation, with a velocity gradient that decreased from $\mathrm{G}=60 / \mathrm{s}( \pm 60 \mathrm{rpm})$ to $\mathrm{G}=20 / \mathrm{s}( \pm 30 \mathrm{rpm})$ over $30 \mathrm{~min}$. Mixing was stopped and the flocs were allowed to settle for $30 \mathrm{~min}$. The settled water passed through a four-stage, downflow sand filter (Table 1) and was then chlorinated with sodium hypochlorite $(\mathrm{NaClO})$ for $30 \mathrm{~min}$. The aluminum sulfate $\mathrm{Al}_{2}\left(\mathrm{SO}_{4}\right)_{3}$ dose depended on the turbidity of the water that varied with the concentration of each pathogen inoculum and was established in preliminary jar tests, in which the $\mathrm{Al}_{2}\left(\mathrm{SO}_{4}\right)_{3}$ dose resulting in the lowest residual turbidity after sand filtration was determined. Water $\mathrm{pH}$ was adjusted with calcium carbonate $\left(\mathrm{CaCO}_{3}\right)$ so that, after coagulant addition, the $\mathrm{pH}$ was between 5.5 and 7.5.

For each pathogen tested, the inoculum volume added once in the jar (2 liters) was adjusted to obtain the final concentration previously described. Samples $(50 \mathrm{ml})$ from each treatment (contaminated raw water, filtered water, and chlorinated water) were collected in sterile Falcon tubes (TPP, model 901050). For each pathogen, the experiment was carried out twice, each one with three treatments and six replications, one jar being considered one experimental unit.

Detection of pathogens in contaminated raw and treated water samples. To detect bacterial pathogens, 1-ml subsamples were subjected to 10 -fold serial dilution $\left(10^{-1}\right.$ to $\left.10^{-8}\right)$ in Eppendorf tubes containing $900 \mu \mathrm{l}$ of sterile saline $+0.05 \%$ Tween solution. Dilutions were transferred by the microdrop technique (10 $\mu \mathrm{l})(25)$ to petri plates $(9 \mathrm{~cm})$ containing solid 523 medium (24) supplemented with rifamycin $\mathrm{SV}$ at $0.2 \mathrm{mg} / \mathrm{ml}$ ( $R$. solanacearum) or 0.1 $\mathrm{mg} / \mathrm{ml}$ (X. axonopodis). After incubation at $28^{\circ} \mathrm{C}$ for $48 \mathrm{~h}$ in the dark, CFU were quantified.

To detect $B$. cinerea and $C$. candelabrum, water samples were analyzed using the biological bait method $(16,28)$. Water samples from each treatment $(50 \mathrm{ml}$ each) were used to moisten $70 \mathrm{~g}$ of sterilized, medium-grain vermiculite in Gerbox containers (13 by 13 by $4 \mathrm{~cm}$ ). Castor bean (Ricinus communis L.) leaf discs ( 9 $\mathrm{mm}$ ) used as biological baits were disinfested in $50 \%$ ethanol for $30 \mathrm{~s}$, followed by immersion in $5 \% \mathrm{NaClO}$ for $3 \mathrm{~min}$, then washed three times in sterile water. Thirty bait disks were placed in the vermiculite and the containers incubated in the dark at $20^{\circ} \mathrm{C}$ (B. cinerea) or $26^{\circ} \mathrm{C}$ (C. candelabrum) for $48 \mathrm{~h}$. The disks were removed, disinfested as previously described, and transferred to petri plates $(9 \mathrm{~cm})$ containing PDA. After 5 days of incubation, the plates were examined under a stereoscopic microscope for the presence of typical structures of the fungal pathogens. The percentage of colonized baits per treatment was calculated. Sterilized vermiculite moistened with sterile water was used as the control.

Disease intensity in eucalypt cuttings and tomato seedlings inoculated with contaminated raw and treated water. In addition to the in vitro tests, inactivation of each pathogen by both ultrafiltration and physical-chemical treatment was evaluated by inoculating plants through irrigation with either contaminated raw or treated water. In the ultrafiltration experiment, the contaminated raw water and ultrafiltered water were collected once on the first day of operation and used to irrigate 10 plants. In the physicalchemical treatments, the contaminated raw water, filtered water,

Table 1. Grain size distribution of layers in the down-flow sand filters

\begin{tabular}{llc}
\hline Layer & Size $(\mathbf{m m})$ & Thickness $(\mathbf{c m})$ of sand layers \\
\hline 1 & $0.25-1.0$ & 15 \\
2 & $1.0-2.0$ & 2 \\
3 & $2.0-4.76$ & 1 \\
4 & $4.76-9.52$ & 4 \\
\hline
\end{tabular}


and chlorinated water were applied on 12 plants ( 2 plants/each treatment/jar). The experiment was carried out twice.

All inoculation experiments were in a completely randomized design, and distilled water was used as a negative control. For Ralstonia solanacearum, a soilborne pathogen, the roots were inoculated; whereas, for the aerial plant pathogens ( $B$. cinerea and $C$. candelabrum), the treated and untreated water were sprayed on the plants.

Twenty-day-old tomato seedlings were used to bioassay for $R$. solanacearum. The seedlings were held for $24 \mathrm{~h}$ without irrigation; then, one-third of their root system was cut and the remaining roots immersed for $20 \mathrm{~min}$ in approximately $50 \mathrm{ml}$ of each type of water. The seedlings were transplanted to $300-\mathrm{ml}$ plastic pots (Zanatta Descartáveis, model CZ 300) containing pathogenic inoculum-free substrate prepared with pine bark (Mecplant) and placed in a growth chamber at $26^{\circ} \mathrm{C}$. After 15 days, all seedlings were subjected to the bacterial exudate test to assess the presence of the bacterium.

Mini-cuttings of Eucalyptus globulus were used to bioassay for B. cinerea. The mini-cuttings of about $8 \mathrm{~cm}$ long, with two leaf pairs containing half of the sectioned leaf blade, were planted in 80-ml plastic pots (Zanatta Descartáveis, model C80CR) containing pathogenic inoculum-free substrate prepared with pine bark (Mecplant). Following spray inoculations (Gifor, model US-2500 $\mathrm{SC})$ with contaminated raw water or treated water, the mini-cuttings were kept in a moist chamber at $22^{\circ} \mathrm{C}$ for 15 days, after which disease incidence was evaluated by observing dead cuttings, necrotic leaves, or presence of typical pathogen structures.

Sixty-day-old cuttings of hybrid clone 9882 (E. grandis $\times E$. urophylla) were used to bioassay for $C$. candelabrum. After spray inoculating (Gifor, model US-2500 SC) with raw, contaminated water and treated water in sufficient quantity to uniformly cover both sides of the leaves without causing surface runoff, the plants were kept in a fog chamber at $25^{\circ} \mathrm{C}$ for $48 \mathrm{~h}$ and then transferred to the greenhouse $\left(26 \pm 5^{\circ} \mathrm{C}\right)$. After 10 days, lesion area $(\%)$ on the fourth completely expanded leaf pair in each cutting was quantified by digital image analysis using the Software Quant (51).

Statistical analysis. The averages of eradication and standard deviations were calculated for each pathogen and each method of water treatment. To determine the minimum effective chlorine concentration to eradicate each pathogen, $\mathrm{CFU} /$ milliliter data were $\log$ transformed and the data of the two independent experiments were calculated separately in order to use the larger residual chlorine values that lowered $\mathrm{CFU}$ to zero and not to base the conclusions on the average of the two experiments. A preliminary analysis of variance indicated no significant differences between the two experiments conducted for minimum effective chlorine concentration. Thus subsequent analyses ( $t$ test and Pearson correlation) were performed on data averaged over the two experiments. The controls, with and without sodium thiosulfate, were compared by $t$ test at significance level $\alpha=0.05$. Pearson correlation coefficients were calculated for the data of applied chlorine or residual chlorine and $\log \mathrm{CFU}$ for a pathogen. All statistical analyses were carried out using SAS (version 9.0; The SAS Institute Inc.).

\section{Results}

Ultrafiltration of contaminated water. Membrane ultrafiltration proved highly effective in removal of both bacterial and fungal pathogens. Ultrafiltration removed $99.9 \%$ of $R$. solanacearum (Table 2). The initial concentration in the contaminated raw water was $8 \times 10^{7}$ and $3 \times 10^{5} \mathrm{CFU} / \mathrm{ml}$ for the first and last days, respectively, of filter operation (Fig. 3). The ultrafiltered water collected on the first day of operation contained only $44 \mathrm{CFU} / \mathrm{ml}$, insufficient to cause bacterial wilt or bacterial exudate. On the other hand, $90 \%$ of plants treated with contaminated raw water exhibited bacterial exudate (Table 2). More than $99.8 \%$ of $X$. axonopodis were removed by ultrafiltration (Table 2). However, the concentration in the contaminated raw water remained high during the experimental period, with $1.5 \times 10^{8}$ and $7 \times 10^{5} \mathrm{CFU} / \mathrm{ml}$ for the first and last days, respectively, of ultrafiltration unit operation (Fig. 3).

Bait colonization was above $65 \%$ for $B$. cinerea and $54 \%$ for $C$. candelabrum in the presence of contaminated raw water (Fig. 3). Ultrafiltration completely removed $B$. cinerea, except on the fifth day of operation, which resulted in $99.9 \%$ removal, and no incidence of disease was found in mini-cuttings sprayed with treated water (Table 2). C. candelabrum was completely removed during the entire period of operation of the ultrafiltration unit, although leaf lesions were found to a small extent on eucalypt cuttings sprayed with treated and distilled water (control; Table 2). These lesions were probably caused by pathogen contamination in the environment or, perhaps, drift during inoculation experiments.

Minimum chlorine residual for plant pathogen inactivation. Negative correlations were found between applied chlorine and log CFU, as well as between residual chlorine and $\log \mathrm{CFU}$, for all pathogens tested (Table 3), demonstrating the efficacy of chlorine disinfection. In the first experiment, chlorine residuals that eradicated $R$. solanacearum, $X$. axonopodis, $B$. cinerea, and $C$. candelabrum were $1.17,1.6,0.4$, and $0.31 \mathrm{mg} / \mathrm{liter}$, respectively; and, in the second experiment, they were $1.7,1.74,0.63$, and $0.52 \mathrm{mg} / \mathrm{liter}$, respectively (Fig. 4). The minimum chlorine residual necessary to guarantee inactivation of all pathogens was between 1.6 and 1.74 $\mathrm{mg} / \mathrm{liter}$. No significant difference was found in growth of controls with or without thiosulfate addition (Table 4), proving that residual chlorine did not affect pathogens growth.

Efficacy of physical-chemical treatment of contaminated water. Although physical-chemical treatment was partially effective, complete pathogen removal was only possible after chlorination, except in the case of $C$. candelabrum, that was eliminated after sand filtration (Table 5). The number of $R$. solanacearum cells found after filtration was $3.8 \times 10^{5} \mathrm{CFU} / \mathrm{ml}$ (Fig. 5). This inoculum concentration was sufficient to induce bacterial exudate in tomato seedlings (Table 5). Filtration was less effective for $X$. axonopodis than for $R$. solanacearum, resulting in inoculum concentrations of $2.4 \times 10^{6} \mathrm{CFU} / \mathrm{ml}$ (Fig. 5).

Filtration effectiveness for $B$. cinerea was lower because of poor flocculation efficiency in one of the repetitions (jars), which resulted in low spore removal and high incidence of infected cuttings

Table 2. Average of eradication (\%) of Ralstonia solanacearum, Xanthomonas axonopodis, Botrytis cinerea, and Cylindrocladium candelabrum and intensity of disease (\%) caused by these pathogens in plants irrigated with contaminated raw and treated irrigation water by ultrafiltration

\begin{tabular}{|c|c|c|c|c|}
\hline \multirow[b]{2}{*}{ Species } & \multirow[b]{2}{*}{ Eradication $(\%)^{\mathbf{b}}$} & \multicolumn{3}{|c|}{ Disease intensity $(\%)^{\mathbf{a}}$} \\
\hline & & Raw water & Ultrafiltered water & Distilled water (control) \\
\hline R. solanacearum ${ }^{\mathrm{c}}$ & $99.9(0.002)$ & 90 & 0 & 0 \\
\hline X. axonopodis & $99.8(0.292)$ & na & na & na \\
\hline B. cinerea $^{\mathrm{d}}$ & $99.9(0.614)$ & 70 & 0 & 0 \\
\hline C. candelabrum $\mathrm{e}$ & $100(0.000)$ & $2.9(0.003)$ & $0.2(0.001)$ & $0.2(0.001)$ \\
\hline
\end{tabular}

${ }^{a}$ Disease intensity values are means over 10 inoculated plants. Values between parentheses are the standard deviation; na = not analyzed.

${ }^{\mathrm{b}}$ Eradication values are means of seven repetitions, each one with three replications.

${ }^{\mathrm{c}}$ Incidence $(\%)$ of bacterial exudate in tomato seedlings.

${ }^{\mathrm{d}}$ Incidence $(\%)$ of $B$. cinerea in eucalyptus mini-cuttings.

e Area of foliar lesions (\%) in eucalypt cuttings. 
(Table 5). Physical-chemical treatment was only effective for $B$. cinerea removal after chlorination, as was found for the bacterial pathogens. On the other hand, filtration was sufficient to eliminate C. candelabrum. Foliar lesions in cuttings were lower after water treatment (Table 5). The low disease intensity observed in cuttings sprayed with treated or distilled water (control) was attributed to spores present in the environment or, perhaps, drift during inoculation experiments.

\section{Discussion}

Both methods of irrigation water treatment evaluated in this study were efficient in removing plant pathogens. Ultrafiltration completely eliminated fungal conidia, except for $B$. cinerea on 1 day of treatment. This 1 day may have been a result of contamination during manipulation of the baits employed to detect the pathogen. Close to $100 \%$ elimination of bacterial pathogens was achieved and the low quantities of pathogens remaining did not induce any disease symptoms in inoculated plants. The high inocu- lum concentrations used in this study, which are not likely to be found in the natural environment, may have led to reduced treatment efficiency.

During ultrafiltration, water passes through pores in synthetic membranes that retain components of larger size. Membranes used in this study had a cutoff of $0.05 \mu \mathrm{m}$ and where expected to completely eliminate bacteria (average size of 1 by $3 \mu \mathrm{m}$ ). Treatment of encysted Pythium myriotylum zoospores ( 8 to $10 \mu \mathrm{m})$ using membranes alone (1- to $5-\mu \mathrm{m}$ pore size) or in series (1- and $0.5-\mu \mathrm{m}$ pore-size) also did not totally eliminate the pathogen (42). Zoospores of Pythium and Phytophthora spp. were also found to pass through membranes with pores of 0.4 and $0.45 \mu \mathrm{m}$ (22). Spore passage through membrane pores may be attributed to small atypical spores, defects in membrane seals, or excessive pump pressure (42). Furthermore, nominal pore diameters are average values, which means that not all pores have the same diameter and largerthan-average pores can permit passage of some plant pathogens. Almost complete removal of $R$. solanacearum (Pseudomonas sola-
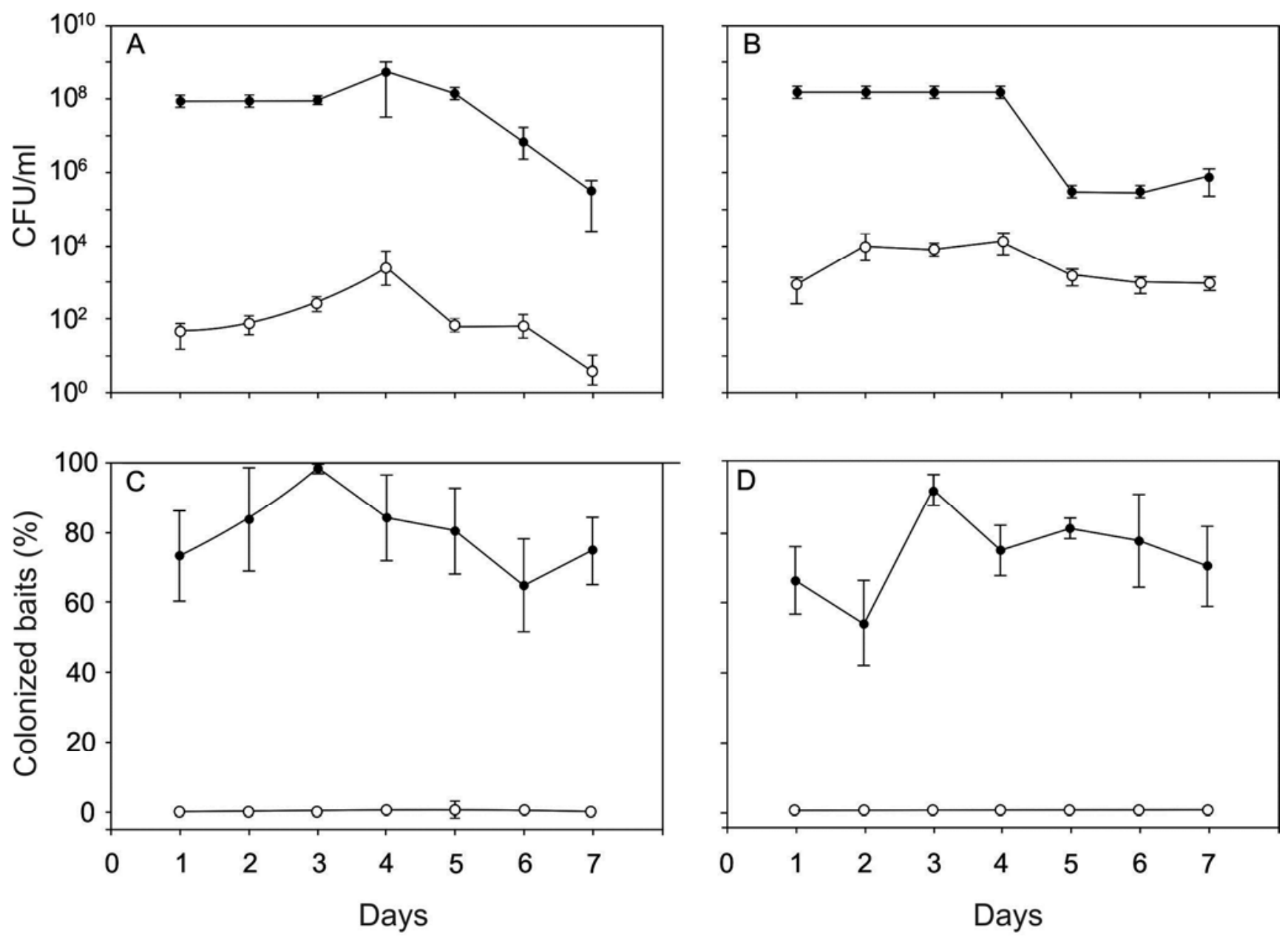

$\longrightarrow$ Raw contaminated water $-\mathrm{O}$ - Treated water

Fig. 3. Variation of inoculum in contaminated raw water and water treated by ultrafiltration. A, Ralstonia solanacearum; B, Xanthomonas axonopodis; C, Botrytis cinerea; and D, Cylindrocladium candelabrum. Each point is the average of nine observations. Bars represent standard deviation.

Table 3. Pearson correlation coefficients (R) between either applied chlorine or residual chlorine and log CFU/milliliter for Ralstonia solanacearum, Xanthomonas axonopodis, Botrytis cinerea, and Cylindrocladium candelabrum

\begin{tabular}{lcccc}
\hline & \multicolumn{3}{c}{ Log $(\mathbf{C F U} / \mathrm{ml})^{\mathbf{a}}$} \\
\cline { 2 - 5 } Chlorine & R. solanacearum & X. axonopodis & B. cinerea & C. candelabrum \\
\hline Applied chlorine $(\mathrm{mg} / \mathrm{liter})$ & -0.81 & -0.84 & -0.71 & -0.67 \\
Residual chlorine $(\mathrm{mg} / \mathrm{liter})$ & -0.79 & -0.81 & -0.59 & -0.57 \\
\hline
\end{tabular}

${ }^{a}$ Data are means of two independent experiments, each one with five replications. For all $\mathrm{R}$ values, $P<0.0001$. 
nacearum) was also reported by Ohtani et al. (35) using a 10- $\mu \mathrm{m}$ prefilter followed by $0.1-\mu \mathrm{m}$ pore size membranes. Better results were found when two or more membranes with different porosities were used in series $(15,22,47)$.

Chlorination of ultrafiltered water can be a complementary measure to guarantee pathogen removal, especially for bacterial pathogens. Chlorine is the most widely used disinfectant in water treatment because it possesses broad-spectrum toxicity toward plant pathogens $(3,7,8,19,23,38)$, is economical, and produces a residual. The minimum chlorine residual necessary to remove all pathogens tested was 1.6 to $1.74 \mathrm{mg} / \mathrm{liter}$, similar to results found for other pathogens $(5,23,39,49)$. Chlorine efficiency depends on the binomial concentration $\times$ time of contact. For shorter treatment times, it is necessary to increase the residual chlorine concentration to ensure inactivation $(3,6,8,23,30,43)$. For example, Spotts and Peters (48) found that complete elimination of $B$. cinerea could be achieved with $50 \mathrm{mg} / \mathrm{liter}$ at a contact time of only $0.5 \mathrm{~min}$.

The minimum residual chlorine concentration used in irrigation water for pathogen eradication must not be toxic to plants. In this

Table 4. Growth ( $\log \mathrm{CFU}$ ) of Ralstonia solanacearum, Xanthomonas axonopodis, Botrytis cinerea, and Cylindrocladium candelabrum with (+) or without (-) sodium thiosulfate addition ${ }^{\mathrm{a}}$

\begin{tabular}{lccc}
\hline Species & - & + & $\boldsymbol{P}$ \\
\hline R. solanacearum & 7.89 & 7.78 & 0.26 \\
X. axonopodis & 7.89 & 7.87 & 0.94 \\
B. cinerea & 4.18 & 4.2 & 0.82 \\
C. candelabrum & 3.97 & 3.95 & 0.55
\end{tabular}

a Data are means of two independent experiments, each one with five replications. Data were compared by $t$ test at $\alpha=0.05$.

E1 R. solanacearum $\quad$ E2

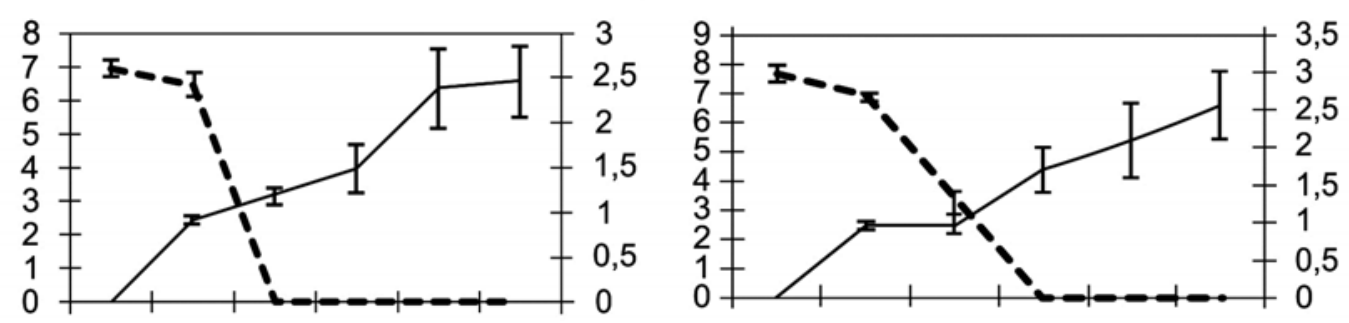

$X$. axonopodis

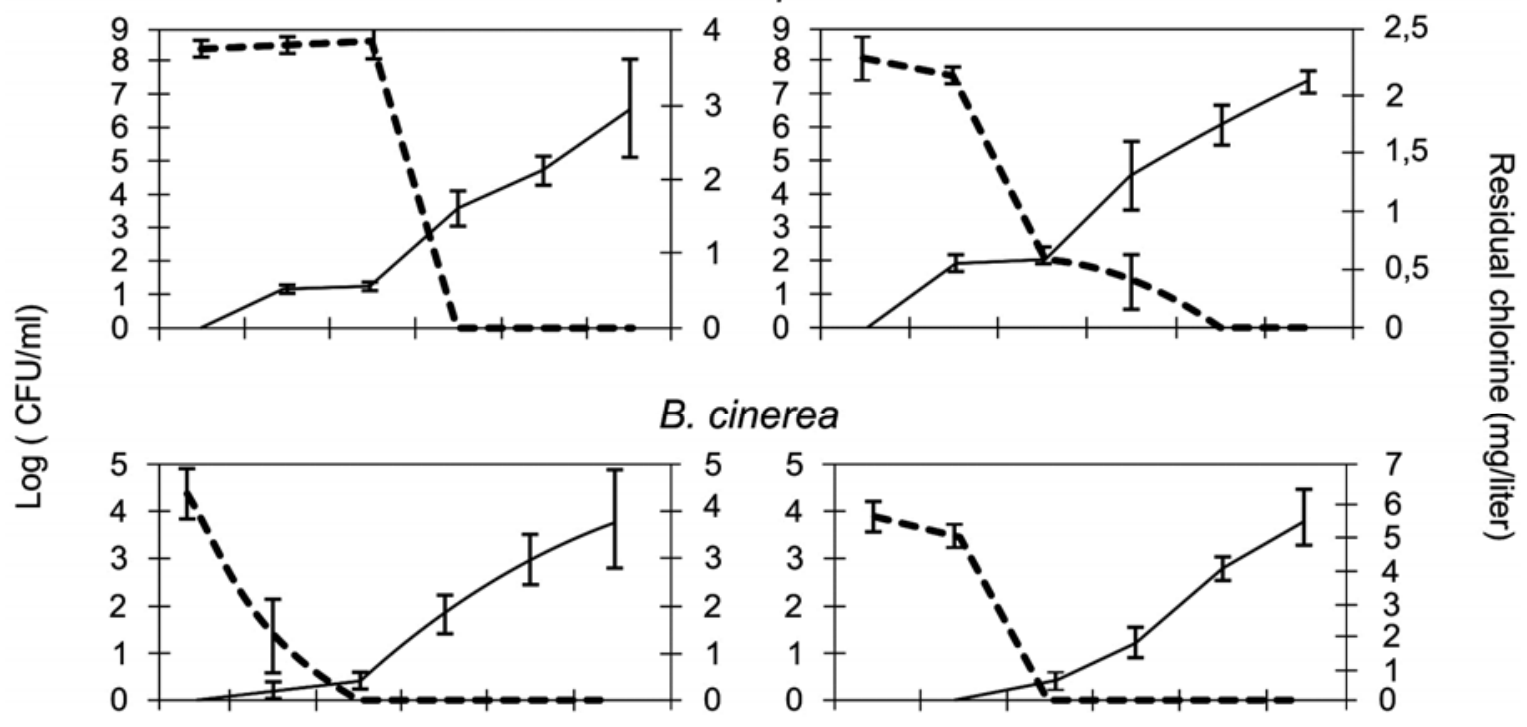

C. candelabrum

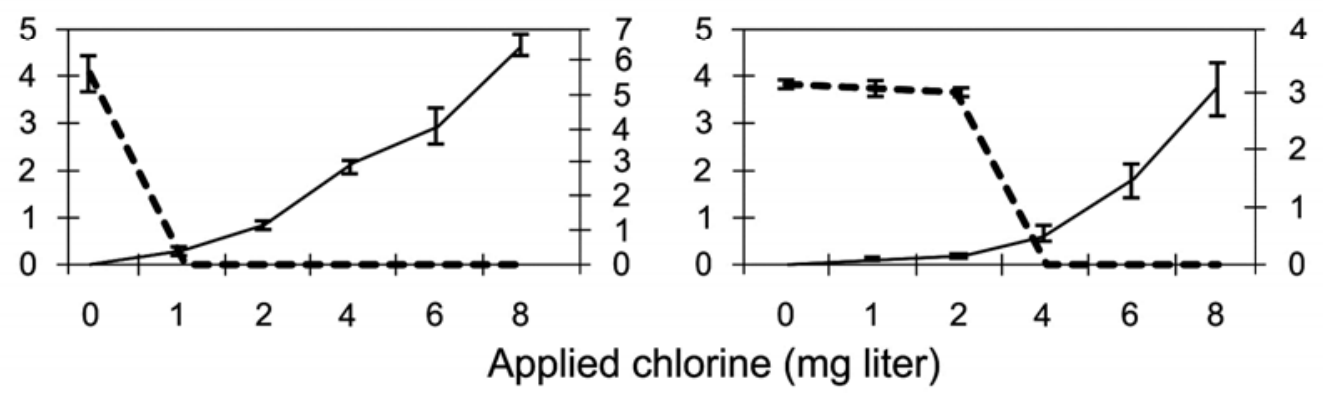

\section{---- Log colony forming unit (CFU/ml) _— Residual chlorine ( $\mathrm{mg} /$ /iter)}

Fig. 4. Effect of residual chlorine on removal of Ralstonia solanacearum, Xanthomonas axonopodis, Botrytis cinerea, and Cylindrocladium candelabrum with different amounts of applied chlorine in two independent experiments (E1 and E2). Curves were constructed with mean values $(n=5)$ and error bars represent \pm one standard deviation. 
study, the necessary residual chlorine is less than $2 \mathrm{mg} /$ liter. This value is within the range for Brazilian standards for public water treatment, in which the residual chlorine should range from 0.2 to $2 \mathrm{mg} / \mathrm{liter}$. This water is used to irrigate plants in parks and gardens and has not shown to be phytotoxic. In a preliminary test (data not shown), irrigation of eucalypt cuttings with water containing residual chlorine at 1.74 to 2.0 and 3.4 to $4.0 \mathrm{mg} / \mathrm{liter}$ for 45 days did not induce any phytotoxic symptoms. Residual chorine values above $2.0 \mathrm{mg} /$ liter were also not phytotoxic in other crops $(5,8,19,38)$.

Physical-chemical treatment was efficient for irrigation water treatment because all plant pathogens tested were completely removed after chlorination. Filtration was sufficient for $C$. candelabrum, probably because of the larger conidial size ( 4.5 by $60 \mu \mathrm{m})$ compared with $B$. cinerea (8 by $11 \mu \mathrm{m})$. However, for the other pathogens, although filtration resulted in greater than $90 \%$ re- moval, the pathogens remaining induced plant disease. Therefore, chlorination is fundamental for pathogen inactivation. To guarantee chlorination efficiency, the residual chlorine concentration must be monitored and maintained at all irrigation points.

Treatment steps prior to chlorination are also important because they partially or totally remove suspended solids (turbidity) and ensure more complete pathogen removal. Irrigation water turbidity should be less than 1.0 nephelometric turbidity units (NTU) and $\mathrm{pH}$ below 8 because both values directly influence residual chlorine (26). In this study, chorine was not tested alone (without prior treatment) because our objective in using chlorine was to minimize the risk of contamination between the water treatment plant and the point of irrigation. It is well known that organic matter present in water can react with chlorine and reduce its disinfection potential. Thus, disinfestation will be easier, more effective, and cheaper if the water is pretreated before adding

Table 5. Average of eradication (\%) of Ralstonia solanacearum, Xanthomonas axonopodis, Botrytis cinerea, and Cylindrocladium candelabrum and disease intensity $(\%)$ caused by these pathogens in plants irrigated with raw water (Raw), filtered water (Filter), and filtered plus chlorinated water (Filter + chlorine) treatments ${ }^{\mathrm{a}}$

\begin{tabular}{|c|c|c|c|c|c|c|}
\hline \multirow[b]{2}{*}{ Species } & \multicolumn{2}{|c|}{ Eradication $(\%)^{\mathbf{b}}$} & \multicolumn{4}{|c|}{ Disease intensity $(\%)^{\mathrm{c}}$} \\
\hline & Filter & Filter + chlorine & Raw & Filter & Filter + chlorine & Control \\
\hline R. solanacearum ${ }^{\mathrm{d}}$ & $99.5(0.5)$ & 100 & 79.2 & 45.8 & 0 & 0 \\
\hline$X$. axonopodis & $97.2(1.9)$ & 100 & na & na & na & na \\
\hline B. cinerea $^{\mathrm{e}}$ & $92.8(12.3)$ & 100 & 87.5 & 20.8 & 0 & 0 \\
\hline C. candelabrum ${ }^{\mathrm{f}}$ & $100(0.0)$ & 100 & $11.9(3.7)$ & $0.1(0.1)$ & $0.1(0.1)$ & $0.1(0.2)$ \\
\hline
\end{tabular}

${ }^{\mathrm{a}}$ Control = distilled water; values between parentheses are the standard deviation; na $=$ not analyzed.

${ }^{\mathrm{b}}$ Eradication values are means of two independent experiments, each one with six replications.

${ }^{\mathrm{c}}$ Disease intensity values are means of two independent experiments, each one with 12 replications.

${ }^{\mathrm{d}}$ Incidence $(\%)$ of bacterial exudate in tomato seedlings.

${ }^{\mathrm{e}}$ Incidence (\%) of B. cinerea in eucalyptus mini-cuttings.

${ }^{\mathrm{f}}$ Area of foliar lesions (\%) in eucalypt cuttings.
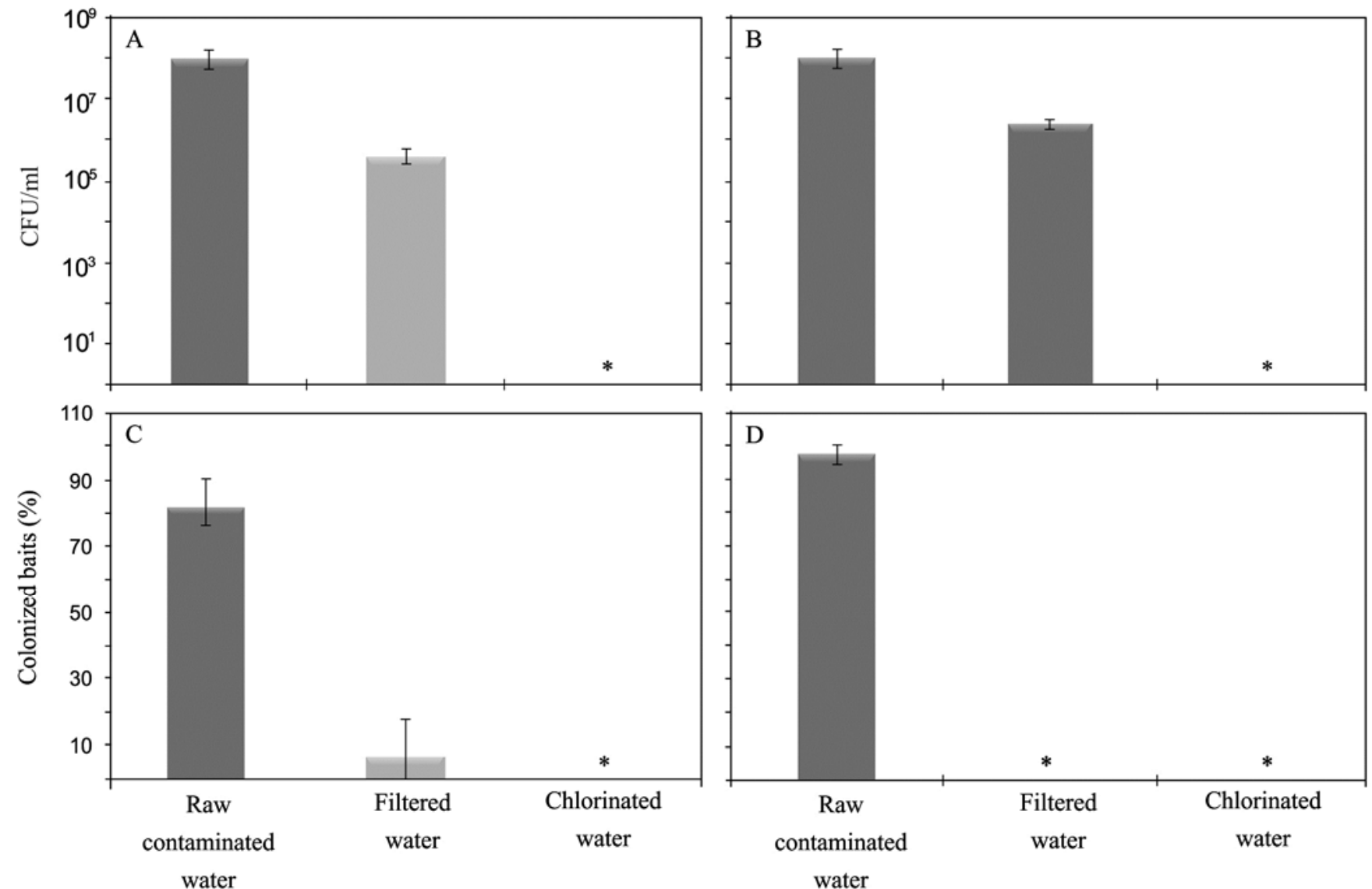

Fig. 5. Inoculum concentration in contaminated raw water, filtered water, and chlorinated water by physical-chemical treatment. A, Ralstonia solanacearum; B, Xanthomonas axonopodis; C, Botrytis cinerea; and D, Cylindrocladium candelabrum. Data are means of two independent experiments, each one with six replications. Bars represent standard deviation. 
chlorine. Sholberg and Owen (45) demonstrated how important filtration before disinfestation is. They tested filtration, chlorination, and chlorination after filtration. Only the sand filter system reduced the Penicillium expansum inoculum concentration but did not remove the risk of contamination. The lowest inoculum concentration was found after addition of $12 \%$ sodium hypochlorite. The best results were obtained when sand filtration and chlorination were used in combination. Furthermore, filtered water required a $17 \%$ lower chlorine dose than unfiltered water.

For resistant plant pathogen structures such as sclerotia, the chlorine concentrations used in this study may not be sufficient. Resistant protozoan structures often found in public water treatment plants such as Giardia cysts $(8$ to $15 \mu \mathrm{m})$ and Cryptosporidium oocysts ( 4 to $6 \mu \mathrm{m}$ ) can be eliminated by flocculation, sedimentation, and sand filtration (21). Sand filtration was able to remove more than $99 \%$ of Cryptosporidium parvum oocysts after coagulation and flocculation (14)

The four pathogens tested here are commonly found in Brazilian eucalypt clonal nurseries and can be present in contaminated water. Despite being a soilborne pathogen, $R$. solanacearum can be easily spread by irrigation water $(20,56)$. In 2005 , the occurrence of this pathogen in Brazilian eucalyptus clonal hedges resulted in loss of approximately U.S.\$3 million and contaminated water was considered one of the potential inoculum sources (1).

Slow sand filtration was efficient in eradicating $R$. solanacearum, B. cinerea, and Cylindrocladium candelabrum but requires a large area for filter construction, which limits its use to small units such as greenhouses and mini-clonal hedges (12). Filters also require manual cleaning and are prone to frequent clogging. In our study, both treatment methods were highly efficient but they also present disadvantages. Physical-chemical treatment consumes chemical products and produces sludge that must be disposed of properly. Ultrafiltration does not have these disadvantages but is more costly to operate. Both conventional physical-chemical and ultrafiltration methods are used to treat water for domestic and industrial use.

Our experiments do not perfectly simulate a real nursery situation. The presence of particulate and organic matter can affect water treatment efficiency and, therefore, pre-treatment such as sand filtration is necessary to remove such substances. In the case of ultrafiltration, the process ensures the retention of all particulate matter and colloids larger than the average pore diameter $(0.05 \mu \mathrm{m})$ while dissolved nutrients such as $\mathrm{N}, \mathrm{P}$, and $\mathrm{K}$ can pass freely through the membrane. In the case of physical-chemical treatment, the coagulant and flocculant doses will need to be optimized in the same way as is done for the drinking water treatment, and will depend on each nursery's water quality. It is unlikely that nutrients or other dissolved substances will interact with the system.

It was not the objective of this study to include an economic analysis because the cost for each system depends upon the size of the plant, the automation level, and the location. Therefore, it is difficult to determine which technology should be used based on costs. A site-specific study it is necessary to select the most costeffective method based on the needs and reality of each forest nursery.

Reuse of irrigation water results in water and nutrient economies and should be considered as an environmentally correct practice $(4,46)$. However, reused water may be contaminated and become an important means of spreading plant pathogens. In the present study, both physical-chemical and ultrafiltration treatments proved to be viable and safe pathogen removal methods.

\section{Acknowledgments}

This work was supported by CNPq (National Council of Technological and Scientific Development) and FAPEMIG (Research Support Foundation for Minas Gerais)

\section{Literature Cited}

1. Alfenas, A. C., Mafia, R. G., Sartório, R. C., Binoti, D. H. B., Silva, R. R., Lau, D., and Vanetti, C. A. 2006. Ralstonia solanacearum em viveiros clonais de eucalipto no Brasil. Fitopatol. Bras. 31:357-366.
2. Alfenas, A. C., Zauza, E. A. V., Mafia, R. G., and Assis, T. F. 2009. Clonagem e doenças do eucalipto, 2nd ed. Universidade Federal de Viçosa, Viçosa, MG, Brasil.

3. Bartz, J. A., Eayre, C. G., Mahovic, M. J., Concelmo, D. E., Brecht, J. K. and Sargent, S. A. 2001. Chlorine concentration and the inoculation of tomato fruit in packinghouse dump tanks. Plant Dis. 85:885-889.

4. Brun, R., Settembrino. A., and Couve, C. 2000. Recycling of nutrient solution for rose (Rosa hybrid) in soilless culture. Acta Hortic. 554:183-187.

5. Cayanan, D. F., Dixon, M., and Zheng, Y. 2009. Response of containergrown nursery plants to chlorine used to disinfest irrigation water. Hortscience 44:164-167.

6. Cayanan, D. F., Zhang, P., Liu, W., Dixon, M., and Zheng, Y. 2009. Efficacy of chlorine in controlling five common plant pathogens. Hortscience 44:157-163.

7. Copes, W. E., Chastaganer, G. A., and Hummel, R. L. 2004. Activity of chlorine dioxide in a solution of ions and $\mathrm{pH}$ against Thielaviopsis basicola and Fusarium oxysporum. Plant Dis. 88:188-194.

8. Datnoff, L. E., Kroll, T. K., and Lacy, G. H. 1987. Efficacy of chlorine for decontamination of water infested with resting spores of Plasmodiophora brassicae. Plant Dis.71:734-736.

9. Di Bernardo, L., and Dantas, A. Di B. 2005. Métodos e técnicas de tratamento de água, 2nd ed. RiMa, São Carlos, SP, Brasil

0. Ehret, L. D., Alsinius B., Wohanka W., Menezies G. J., and Utkhede, R. 2001. Disinfestation of recirculating nutrient solutions in greenhouse horticulture. Agronomie 21:323-339.

11. Faulkner, L. R., and Bolander, W. J. 1970. Agriculturally polluted irrigation water as a source of plant-parasitic nematode infestation. J. Nematol. 2:368374.

12. Ferreira, M. A. Alfenas, A. C., Binoti, D. H. B., Machado, P. S., and Mounteer, A. H. 2012. Slow sand filtration eradicates eucalypt clonal nursery plant pathogens from recycled irrigation water in Brazil. Trop. Plant Pathol. 37.319:325.

13. Gent, D. H., Lang, J. M., Bartolo, M. E., and Schwartz, H. F. 2005. Inoculum sources and survival of Xanthomonas axonopodis pv. allii in Colorado. Plant Dis. 89:507-514.

14. Gitis, V. 2008. Rapid sand filtration of Cryptosporidium parvum: effects of media depth and coagulation. Water Sci. Technol. Water Supply. 8:129-134.

15. Goldberg, N. P., Stanghellini, M. E., and Rasmussen, S. L. 1992. Filtration as method for controlling Pythium root rot of hydroponically grown cucumbers. Plant Dis. 76:777-779.

16. Gonçalves, R. C., Alfenas, A. C., Maffia, L. A., and Crous, P. W. 2001 Evaluation of biossays to quantify Cylidrocladium inocula in soil. Mycoscience 42:261-264.

17. Graça, R. N., Alfenas, A. C., Maffia, L. A., Titon, M., Alfenas, R. F., Lau, D., and Rocabado, J. M. A. 2009. Factors influencing infection of eucalypts by Cylindrocladium pteridis. Plant Pathol. 58:971-981.

18. Graves, L. M., and Swaminathan, B. 1993. Universal bacterial DNA isolation procedure. Pages 617-621 in: Diagnostic Molecular Microbiology: Principles and Applications. D. H. Persing, T. F. Smith, F. C. Tenover, and T. J. White, eds. American Society for Microbiology, Washington, DC.

19. Grech, N. M., and Rijkenberg, F. H. J. 1992. Injection of electrolytically generated chlorine into citrus microirrigation systems for the control of certain waterborne root pathogens. Plant Dis. 76:457-461.

20. Ha, Y., Kim, J. S., Denny, T. P., and Schell, M. A. 2012. A rapid, sensitive assay for Ralstonia solanacearumrace 3 biovar 2 in plant and soil samples using magnetic beads and real-time PCR. Plant Dis. 96:258-264.

21. Heller, L., Bastos, R. K. X., Vieira, M. B. C. M., Bevilacqua, P. Di., Brito, L. L. A. de, Mota, S. M. M., Oliveira, A. A., Machado, P. M., Salvador D. P., and Cardoso, A. B. 2004. Oocistos de Cryptosporidium e cistos de Giardia: Circulação no ambiente e riscos à saúde humana. Epidemiol. Serv. Saúde 13:79-92.

22. Hong, C., Richardson, P. A., and Kong, P. 2002. Comparison of membrane filters as a tool for isolating pythiaceous species from irrigation water. Phytopathology 92:610-616.

23. Hong, C. X., Richardson, P. A., Kong, P., and Bush, E. A. 2003. Efficacy of chlorine on multiple species of Phytophthora in recycled nursery irrigation water. Plant Dis. 87:1183-1189.

24. Kado, C. I., and Heskett, M. G. 1970. Selective media for isolation of Agrobacterium, Corynebacterium, Erwinia, Pseudomonas, and Xanthomonas. Phytopathology 60:969-976.

25. Klement, Z., Rudolph, K., and Sands, D. C. 1990. Methods in Phytobacteriology. Akademiai Kiadó, Budapest.

26. Libânio, M. 2005. Fundamentos de Qualidade e Tratamento de Água. Átomo, Campinas, SP, Brasil.

27. MacDonald, J. D., Ali-Shtayeh, M. S., Kabashima, J., and Stites, J. 1994 Occurrence of Phytophthora in recirculated nursery irrigation effluents. Plant Dis. 78:607-611.

28. Mafia, R. G., Alfenas, A. C., Ferreira, E. M., Machado, P. S., Binoti, D. H B., Leite, F. P., and Souza, F. L. 2008. Reuse of untreated irrigation water as a vehicle of inoculum of pathogens in eucalyptus clonal nursery. Trop. Plant Pathol. 33:96-102.

29. Mancuso, P. C. S., and Santos, H. F. dos, eds. 2003. Reuso de Água. Manole. Barueri, SP, Brasil

30. Mari, M., Cembali, T., Baraldi, E., and Casalini, L. 1999. Peracetic acid and 
chlorine dioxide for postharvest control of Monilinia laxa in stone fruits. Plant Dis. 83:773-776.

31. Mujeriego, R., and Asano, T. 1999. The role of advanced treatment in wastewater reclamation and reuse. Water Sci. Technol. 40:1-9.

32. Neher, D., and Duniway, J. M. 1992. Dispersal of Phytophthora parasitica in tomato fields by furrow irrigation. Plant Dis. 76:582-586.

33. Nobre, S. A. M., Maffia, L. A., Mizubuti, E. S. G., Cota, L. V., and Dias, A. P. S. 2005. Selection of Clonostachys rosea isolates from Brazilian ecosystems effective in controlling Botrytis cinerea. Biol. Control 34:132-143.

34. Norman, D. J., Yuen, J. M. F., Resendiz, R., and Boswell, J. 2003. Characterization of Erwinia populations from nursery retention ponds and lakes infecting ornamental plants in Florida. Plant Dis. 87:193-196.

35. Ohtani, T., Kaneko, A., Fukuda, N., Hagiwara, S., and Sase, S. 2000. Development of a membrane disinfection system for closed hydroponics in a greenhouse. J. Agric. Eng. Res. 77:227-232.

36. Oron, G., Gillermana, L., Buriakovskya, N., Bickd, A., Gargir, M., Dolan, Y., Manor, Y., Katze, L., and Haginc, J. 2008. Membrane technology for advanced wastewater reclamation for sustainable agriculture production. Desalination 218:170-180.

37. Pastrick, K. H., and Maiss, E. 2000. Detection of Ralstonia solanacearum in potato tubers by polymerase chain reaction. J. Phytopathol. 148:619-626.

38. Poncet, C., Offroy, M., Bonnet, G., Brun, R., and Zieslin, N. 2001. Disinfection of recycling water in rose cultures. Acta Hortic. 547: 121-126.

39. Roberts, R. G., and Reymond, S. T. 1994. Chlorine dioxide for reduction of postharvest pathogen inoculum during handling of tree fruits. Appl. Environ. Microbiol. 60:2864-2868.

40. Rodrigues, S. B. S. 2007. Análise do uso de água em unidades de produção de mudas de eucalipto. Dissertação de mestrado, Universidade Federal de Viçosa, Viçosa, MG, Brasil.

41. Sanogo, S., and Moorman, G. W. 1993. Transmission and control of Pythium aphanidermatum in an ebb-and-flow subirrigation system. Plant Dis. 77:287-290.

42. Schuerger, A. C., and Hammer, W. 2009. Use of cross-flow membrane filtration in a recirculating hydroponic system to suppress root disease in pepper caused by Pythium myriotylum. Phytopathology 99:597-607.

43. Segall, R. H. 1968. Fungicidal effectiveness of chlorine as influenced by concentration, temperature, $\mathrm{pH}$, and spore exposure time. Phytopathology 58:1412-1414.
44. Shokes, F. M., and McCarter, S. M. 1979. Occurrence, dissemination, and survival of plant pathogens in surface irrigation ponds in southern Georgia. Phytopathology 69:510-516.

45. Sholberg, P. L., and Owen G. R. 1990. Populations of propagules of Penicillium spp. during immersion dumping of apples. Can. Plant Dis. Surv. 70 11:14.

46. Skimina, C. A. 1992. Recycling water, nutrients, and waste in the nursery industry. Hortscience 27:968-971.

47. Spotts, R. A., and Cervantes, L. A. 1993. Use of filtration for removal of conidia of Penicillium expansum from water in pome fruit packinghouses. Plant Dis. 77:828-830.

48. Spotts, R. A., and Peters, B. B. 1980. Chlorine and chlorine dioxide for control of d'Anjou pear decay. Plant Dis. 64:1095-1097.

49. Thompson, D. L. 1965. Control of bacterial stalk rot of corn by chlorination of water in sprinkler irrigation. Crop Sci. 5:369-370.

50. Toze, S. 2006. Reuse of effluent water-benefits and risks. Agric. Water Manage. 80:147-159.

51. Vale, F. X. R., Fernandes Filho, E. I., and Liberato, J. R. 2003. Quant. A software for plant disease severity assessment. Pages in: Proc. 8th Int Congr. Plant Pathol. Christchurch, New Zealand.

52. Vernooij, C. J. M. 1992. Reduction of environmental pollution by recirculation of drain water in substrate cultures. Acta Hortic. 303:9-13.

53. Werres, S., Wagner, S., Brand, T., Kaminski, K., and Seipp, D. 2007. Survival of Phytophthora ramorum in recirculating irrigation water and subsequent infection of Rhododendron and Viburnum. Plant Dis. 91:1034-1044.

54. Wohanka, W. 1992. Slow sand filtration and UV radiation: low cost techniques for disinfection of recirculating nutrient solutions or surface water. Pages 497-511 in: Isosc Proc. 8th Int. Congr. Soilless Cuture. Rustenburg, South Africa.

55. Yabuuchi, E., Kosak, Y., Yano, I., Hotta, H., and Nishiuchi, Y. 1995. Transfer of two Burkholderia and an Alcaligenes species to Ralstonia gen. nov. Proposal of Ralstonia picketti (Ralston, Palleroni and Doudoroff 1973) comb. nov., Ralstonia solanacearum (Smith 1896) comb. nov. and Ralstonia eutropha (Davis 1969) comb. nov. Microbiol. Immunol. 39:897-904.

56. Yao, K., Hsieh, Y., Chang, Y., Chang, C., Cheng, T., and Liao, H. 2010 Inactivation effect of chlorine dioxide on phytopathogenic bacteria in irrigation water. J. Environ. Eng. Manage. 20:157-160. 